Niepełnosprawność. Dyskursy pedagogiki specjalnej

Nr 34/2019

Disability. Discourses of special education

No. 34/2019

Katarzyna Białożyt

Uniwersytet Pedagogiczny im. Komisji Edukacji Narodowej w Krakowie

\title{
Wybrane obszary aktywności polskich seniorów w świetle europejskich raportów Indeksu Aktywnego Starzenia
}

Artykuł ma charakter przeglądowo-porównawczy, zastosowano metodę desk research, opartą na analizie danych zawartych w literaturze przedmiotu, raportach, ekspertyzach. Celem artykułu jest omówienie zagadnień związanych z Indeksem Aktywnego Starzenia (AAI, Active Ageing Index) ze szczególnym uwzględnieniem danych dla Polski.

Słowa kluczowe: Indeks Aktywnego Starzenia, osoby starsze, polityka senioralna, Unia Europejska

\section{Selected areas of activity of Polish seniors in the light of the European Reports of the Active Aging Index}

The article is a comparative review and applies a desk research method based on the analysis of the data from literature, reports, expert opinions. The aim of the article is to discuss issues related to Active Ageing Index (AAI), with particular focus on the data concerning Poland.

Keywords: Active Ageing Index, older people, seniority policy, European Union

\section{Wprowadzenie}

Zwiększająca się liczba osób starszych stanowi naglący problem europejskich społeczeństw, w tym również Polski. Nasz kraj, według danych demograficznych, od 1967 r. jest zaliczany do państw starych demograficznie a w 1980 r. przekroczony został umowny próg starości (Trafiałek 2003: 7). Wydłużenia ludzkiego życie i jednoczesny spadek liczby urodzeń charakteryzują współczesne piramidy wieku wielu narodów. Według danych Głównego Urzędu Statystycznego (GUS 2016; GUS 2017) w Polsce w latach 1989-2016 nastąpił gwałtowny przyrost liczby osób starszych, szczególnie w grupie 60-64 lata oraz 80+.

Wraz z zwiększającą się populacją seniorów, można zaobserwować wydłużenie ludzkiego życia. W społeczeństwie polskim kobiety żyją dłużej niż mężczyźni, 
dlatego też bardzo mocno uwidacznia się feminizacja starości¹. Prognozy demografów wskazują, iż w 2020 r. Polacy będą dożywać 75,8 lat, natomiast Polki 81,8 lat. Według danych Głównego Urzędu Statystycznego w 2050 r. „w miastach mężczyźni będą dożywali wieku 82,5 lat, kobiety 87,5 lat, natomiast na wsi odpowiednio 81,6 i 87,4 lat" (GUS 2014: 121).

Wobec istotnych zmian demograficznych zasadnym staje się podejmowanie tematyki różnych form aktywności osób starszych. Celem artykułu jest ukazanie i porównanie obszarów aktywności europejskich seniorów, bazując na danych zawartych w raportach Indeksu Aktywnego Starzenia (AAI, Active Ageing Index) oraz wskazanie na propozycję zmian w polskiej polityce senioralnej w kontekście uzyskiwanych przez Polskę wyników AAI.

\section{Indeks Aktywnego Starzenia - charakterystyka}

Indeks Aktywnego Starzenie jest stosunkowo nowym narzędziem Unii Europejskiej, wprowadzonym w celu oszacowania poziomu życia seniorów zamieszkujących poszczególne kraje Wspólnoty. Otrzymane wyniki Indeksu obrazują, w jaki sposób osoby starsze uczestniczą w życiu społecznym, gospodarczym, na ile ich potencjał jej wykorzystywany oraz $\mathrm{w}$ jakim stopniu czują się niezależne i bezpieczne (European Commission, United Nations 2015a: 5). Narzędzie to posiada 22 wskaźniki, przyporządkowane do 4 głównych kategorii:

1. Wskaźnik zatrudnienia osób starszych:

- wskaźnik zatrudniania w wieku 55-59 lat;

- -wskaźnik zatrudnienia wieku 60-64 lat;

- wskaźnik zatrudniania w wieku 65-69 lat;

- wskaźnik zatrudniania w wieku 70-74 lat;

2. Aktywność społeczna, partycypacja społeczna:

- udział w wolontariacie osób 55+;

- odsetek osób w wieku 55+, które opiekują się starszymi lub niepełnosprawnymi członkami rodziny;

- odsetek osób w wieku 55+, które co najmniej raz w tygodniu opiekują się swoimi dziećmi/wnukami;

- zaangażowanie osób w wieku 55+ w życie polityczne (udział w związkach zawodowych, partiach politycznych);

$\overline{1}$ Feminizacja starości - wraz z wiekiem wzrasta udział kobiet wśród grupy osób starszych. Według założeń demografów, kobiety będą żyć znacznie dłużej niż mężczyźni, będzie ich również stosunkowo więcej. Feminizacja starości jest cechą specyficzną, mocno uwidaczniającą się w grupie osób $75+$. 
3. Niezależność, zdrowie, bezpieczeństwo

- zaangażowanie osób 55 + w aktywność fizyczną, odsetek osób, które co najmniej 5 razy w tygodniu deklarują uprawnianie aktywności fizycznej;

- dostęp do opieki medycznej;

- odsetek osób 75+, które gospodarują samodzielnie lub ze współmałżonkiem;

- bezpieczeństwo finansowe określane przez stosunek średnich dochodów osób $65+$ do dochodów osób poniżej 65. roku życia;

- brak ryzyka ubóstwa, odsetek osób 65+, które nie są narażone na znalezienie się w grupie osób ubogich (próg ubóstwa ustalony na poziomie $50 \%$ średnich dochodów ogółem);

- odsetek osób 65+, które mają zaspokojone potrzeby o charakterze materialnym;

- bezpieczeństwo fizyczne, odsetek osób w wieku 55+, które nie są w grupie narażonej na bycie ofiarą przemocy;

- edukacja ustawiczna, odsetek osób w wieku 55-74 lat, które uczestniczyły/ uczestniczą w różnych formach edukacji;

4. Zdolność i przygotowanie otoczenia do wykorzystania potencjału osób starszych

- przeciętne, prognozowane trwanie życia dla osób w wieku 50-55 lat;

- przeciętne, prognozowane trwanie życia w zdrowiu w wieku 55+;

- kondycja/zdrowie psychiczne osób w wieku 55+;

- korzystanie z ITC, odsetek osób 55+ które co najmniej raz dziennie korzystają z Internetu;

- więzi społeczne, odsetek osób w wieku 55+ które co najmniej raz w miesiącu spotykają się z przyjaciółmi, krewnymi, znajomymi;

- wykształcenie osób z grupy wiekowej 55-74, odsetek osób które osiągnęly minimum wykształcenie ponadgimnazajalne (Zaidi et al. 2013: 21).

Zaprezentowane identyfikatory dla poszczególnych obszarów AAI, stanowią spójną całość, która przyjmuje wartość od 0 do 100 . Im wyższy, wynik tym wyższa aktywność seniorów w danym państwie (Jurek 2015: 3). Poszczególne obszary Indeksu posiadają odpowiednią wagę, która przekłada się na całościowe wyniki AAI. Waga obszaru zatrudnienia wynosi 35\%, taka sama waga przypisana jest partycypacji społecznej. $10 \%$ przypisuje się obszarowi zdrowia i niezależności natomiast $20 \%$ to waga przygotowania społeczeństwa do wykorzystania potencjału osób starszych (Karpińska, Dykstra 2015: 10).

Powstanie wskaźnika było odpowiedzią na dokonujące się zmiany demograficzne i konieczność podjęcia działań mających na celu zwiększenie udziału osób starszych w partycypacji społecznej. Konstruktywne wykorzystanie potencjału seniorów staje się naglącym zadaniem wielu gospodarek Unii Europejskiej, dlatego też wyniki Indeksu opracowywane i publikowane są co 2 lata, co sprzyja rozpoznaniu zmian i tendencji, jakie zachodzą w krajach Wspólnoty. 


\section{Wyniki Indeksu Aktywnego Starzenia w latach 2010, 2012, 2014}

Pierwsza kategoria AAI charakteryzuje poziom zatrudnienia osób po 55 roku życia. Na rynku pracy dość mocno uwidacznia się proces starzenia społeczeństw i problem zastępowalności pokoleń, a tym samym i pracowników. Zbigniew Strzelecki (2015: 265-266) zauważa, iż obecnie żaden kraj europejski nie ma zagwarantowanej zastępowalności pokoleń. Natomiast w roku 1980 tych państw było aż 9, w tym również Polska. Obciążenie osób w wieku produkcyjnym przez zwiększającą się liczbą osób w wieku poprodukcyjnym bardzo mocno uwidacznia się w krajach Wspólnoty, gdzie według danych w 2008 r. na 1 osobę w wieku powyżej 65 lat, przypadały $4 \mathrm{w}$ wieku produkcyjnym. Jak szacuje Komisja Europejska, w 2060 r. na 1 osobę w wieku poprodukcyjnym będą przypadać tylko $2 \mathrm{w}$ wieku produkcyjnym (Bombiak 2014: 110).

Zachodzące zmiany na rynku pracy wskazują na potrzebę aktywizacji zawodowej najstarszych grup. W tabeli 1 zaprezentowano wyniki Indeksu Aktywnego Starzenia w obszarze zatrudniania za lata 2010, 2012, 2014, ukazane są również pozycje, jakie zajmowały poszczególne kraje w omawianych latach.

Tabela 1. Wskaźnik AAI w obszarze zatrudnia

\begin{tabular}{|l|c|c|c|c|c|c|}
\hline \multicolumn{1}{|c|}{ Państwo } & 2010 & $\begin{array}{c}\text { Pozycja } \\
\text { rankingowa } \\
2010\end{array}$ & 2012 & $\begin{array}{c}\text { Pozycja } \\
\text { rankingowa } \\
2012\end{array}$ & 2014 & $\begin{array}{c}\text { Pozycja } \\
\text { rankingowa } \\
2014\end{array}$ \\
\hline Austria & 23,5 & 18 & 24,6 & 15 & 24,7 & 16 \\
\hline Belgia & 18,1 & 26 & 19,8 & 26 & 21,0 & 24 \\
\hline Bułgaria & 25,8 & 15 & 24,6 & 16 & 25,1 & 15 \\
\hline Chorwacja & 21,7 & 19 & 22,3 & 19 & 21,7 & 23 \\
\hline Cypr & 34,6 & 6 & 36,1 & 2 & 31,4 & 10 \\
\hline Czechy & 26,6 & 14 & 26,4 & 14 & 28,0 & 14 \\
\hline Dania & 34,1 & 7 & 34,0 & 6 & 35,8 & 3 \\
\hline Estonia & 38,6 & 3 & 34,3 & 5 & 39,7 & 2 \\
\hline Finlandia & 31,4 & 10 & 32,0 & 7 & 33,7 & 7 \\
\hline Francja & 19,3 & 21 & 20,9 & 22 & 24,1 & 17 \\
\hline Grecja & 24,9 & 16 & 24,4 & 17 & 20,4 & 25 \\
\hline Hiszpania & 24,4 & 17 & 23,3 & 18 & 23,3 & 18 \\
\hline Holandia & 30,3 & 11 & 31,4 & 9 & 33,9 & 6 \\
\hline Irlandia & 33,4 & 9 & 31,0 & 11 & 30,6 & 12 \\
\hline Litwa & 30,2 & 12 & 27,3 & 13 & 30,5 & 13 \\
\hline Luksemburg & 18,3 & 25 & 21,1 & 21 & 21,9 & 22 \\
\hline Łotwa & 38,8 & 2 & 28,3 & 12 & 32,0 & 9 \\
\hline
\end{tabular}




\begin{tabular}{|l|c|c|c|c|c|c|}
\hline \multicolumn{1}{|c|}{ Państwo } & 2010 & $\begin{array}{c}\text { Pozycja } \\
\text { rankingowa } \\
2010\end{array}$ & 2012 & $\begin{array}{c}\text { Pozycja } \\
\text { rankingowa } \\
2012\end{array}$ & 2014 & $\begin{array}{c}\text { Pozycja } \\
\text { rankingowa } \\
2014\end{array}$ \\
\hline Malta & 16,5 & 27 & 18,7 & 27 & 20,1 & 26 \\
\hline Niemcy & 28,8 & 13 & 31,2 & 10 & 34,4 & 5 \\
\hline Polska & 18,3 & 24 & 19,9 & 25 & 22,4 & 20 \\
\hline Portugalia & 36,6 & 4 & 35,3 & 4 & 32,6 & 8 \\
\hline Rumunia & 33,6 & 8 & 31,4 & 8 & 31,0 & 11 \\
\hline Słowacja & 19,3 & 23 & 20,1 & 24 & 21,9 & 21 \\
\hline Słowenia & 19,3 & 21 & 21,6 & 20 & 19,1 & 28 \\
\hline Szwecja & 40,8 & 1 & 41,6 & 1 & 43,4 & 1 \\
\hline Węgry & 16,4 & 28 & 17,8 & 28 & 19,3 & 27 \\
\hline Wielka Brytania & 34,9 & 5 & 35,5 & 3 & 35,8 & 4 \\
\hline Włochy & 19,6 & 20 & 20,9 & 22 & 23,0 & 19 \\
\hline
\end{tabular}

Źródło: Opracowanie własne na podstawie: Active Ageing Indeks Home - unece, AAI results for EU28, http://www1.unece.org/stat/platform/pages/viewpage.action?pageId=76287845 [dostęp: 13.05.2017]; European Cmmission, United Nations (2014: 5); European Cmmission, United Nations (2015b).

Jak wynika z danych zawartych $\mathrm{w}$ tabeli 1, państwem Unii Europejskiej dominującym $\mathrm{w}$ sferze zatrudniania najstarszych pracowników jest Szwecja, która utrzymuje pozycję lidera aktywizacji zawodowej kohorty 55+. Wysoko znajdują się również takie państwa jak Dania, Estonia, Portugalia. Polska w $2010 \mathrm{r}$. zajmowała 24. miejsce na 28 państw, w 2012 r. widoczny jest spadek na 25. miejsce, natomiast w 2014 r. nasz kraj przesunął się w klasyfikacji na 20 pozycję. W grupie krajów o niskim wskaźniku zatrudnienia osób starszych należy wskazać Węgry, Maltę, Belgię, Słowację, Luksemburg.

Dominacja Szwecji w omawianym obszarze nie zaskakuje, bowiem kraj ten jako pierwszy zrealizował założenia Strategii Lizbońskiej mówiące o zwiększeniu do 2010 roku poziomu zatrudnia osób 55+ do 50\% (Departament Analiz Ekonomicznych i Społecznych: 9). Szwecja w latach 2004-2014 wykazywała się najwyższym wskaźnikiem zatrudnienia najstarszych pracowników w krajach Wspólnoty. Natomiast założenia Strategii Lizbońskiej do 2010 roku zrealizowało tylko 10 państw: Cypr, Szwecja, Niemcy, Dania, Estonia, Finlandia, Irlandia, Holandia oraz Wielka Brytania (Pikuła, Białożyt 2016: 134-133). Dane zaprezentowane w Indeksie Aktywnego Starzenia wskazują iż państwa te utrzymują przewagę nad pozostałymi członkami UE w obszarze aktywizacji zawodowej starszych pracowników, choć dysproporcje i nierówności sukcesywnie przez znaczną część krajów są niwelowane.

Drugim wymiarem, który wpływa na wskaźnik AAI, jest aktywność społeczna i partycypacja społeczna osób starszych $\mathrm{w}$ danych państwach. W tabeli 2 zapre- 
zentowano uzyskane wyniki oraz ranking krajów Unii Europejskiej w latach 2010, 2012, 2014.

Tabela 2. Wskaźnik AAI w obszarze aktywności społecznej

\begin{tabular}{|c|c|c|c|c|c|c|}
\hline Państwo & 2010 & $\begin{array}{c}\text { Pozycja } \\
\text { rankingowa } \\
2010\end{array}$ & 2012 & $\begin{array}{c}\text { Pozycja } \\
\text { rankingowa } \\
2012\end{array}$ & 2014 & $\begin{array}{c}\text { Pozycja } \\
\text { rankingowa } \\
2014\end{array}$ \\
\hline Austria & 15,4 & 12 & 18,2 & 13 & 18,2 & 13 \\
\hline Belgia & 19,3 & 4 & 20,2 & 9 & 20,2 & 9 \\
\hline Bułgaria & 9,1 & 28 & 12,5 & 27 & 12,5 & 27 \\
\hline Chorwacja & 12,0 & 22 & 18,7 & 12 & 18,7 & 12 \\
\hline Cypr & 12,5 & 21 & 18,1 & 14 & 18,1 & 14 \\
\hline Czechy & 11,9 & 23 & 18,8 & 11 & 18,8 & 11 \\
\hline Dania & 17,5 & 8 & 19,6 & 10 & 19,6 & 10 \\
\hline Estonia & 13,0 & 19 & 12,8 & 25 & 12,8 & 25 \\
\hline Finlandia & 17,9 & 7 & 20,5 & 8 & 20,5 & 8 \\
\hline Francja & 20,5 & 3 & 22,8 & 4 & 22,8 & 4 \\
\hline Grecja & 11,1 & 25 & 13,7 & 22 & 13,7 & 22 \\
\hline Hiszpania & 11,4 & 24 & 17,8 & 15 & 17,8 & 15 \\
\hline Holandia & 21,7 & 1 & 22,4 & 5 & 22,4 & 5 \\
\hline Irlandia & 15,1 & 13 & 24,1 & 1 & 24,1 & 1 \\
\hline Litwa & 12,9 & 20 & 14,7 & 19 & 14,7 & 19 \\
\hline Luksemburg & 16,7 & 9 & 22,2 & 6 & 22,2 & 6 \\
\hline Łotwa & 13,4 & 15 & 13,8 & 21 & 13,8 & 21 \\
\hline Malta & 14,4 & 14 & 17,3 & 16 & 17,3 & 16 \\
\hline Niemcy & 16,6 & 11 & 13,6 & 24 & 13,6 & 24 \\
\hline Polska & 13,3 & 17 & 12,1 & 28 & 12,1 & 28 \\
\hline Portugalia & 10,2 & 27 & 14,1 & 20 & 14,1 & 20 \\
\hline Rumunia & 10,2 & 27 & 12,7 & 26 & 12,7 & 26 \\
\hline Słowacja & 13,2 & 18 & 13,7 & 23 & 13,7 & 23 \\
\hline Słowenia & 16,6 & 10 & 16,3 & 17 & 16,3 & 17 \\
\hline Szwecja & 21,0 & 2 & 22,9 & 3 & 22,9 & 3 \\
\hline Węgry & 13,4 & 16 & 15,4 & 18 & 15,4 & 18 \\
\hline Wielka Brytania & 18,0 & 6 & 21,6 & 7 & 21,6 & 7 \\
\hline Włochy & 18,4 & 5 & 24,1 & 2 & 24,1 & 2 \\
\hline
\end{tabular}

Źródło: Opracowanie własne na podstawie: opracowanie własne na podstawie: Active Ageing Indeks Home - unece, AAI results for EU28, http://www1.unece.org/stat/platform/pages/viewpage.action?pageId =76287845 [dostęp: 13.05.2017]; European Cmmission, United Nations (2014: 5); European Cmmission, United Nations (2015b). 
Najwyższy wskaźnik udziału osób starszych w życiu społecznym odnotowano w Irlandii, która w roku 2012 oraz 2014 zajęła 1. miejsce wśród państw Unii Europejskiej. Wśród liderów należy również wskazać na Włochy, Szwecja, Holandia, Francja. Polska w 2010 r. uzyskała 17. pozycję, jednak w 2012 r. oraz 2014 r. osiągnęła najniższy wskaźnik aktywności społecznej osób starszych w całej Wspólnocie. Spadek o 11 miejsc rankingowych i utrzymanie ostatniej pozycji $\mathrm{w}$ dwóch kolejnych pomiarach AAI wskazuję na potrzebę podjęcia działań z zakresu aktywizacji i partycypacji seniorów w naszym kraju. Biorąc pod uwagę tendencje demograficzne oraz prognozy, zasadnym staje się skupienie na tym obszarze funkcjonowania najstarszych grup wiekowych w Polsce. Niski wskaźnik w omawianym obszarze odnotowano również w Bułgarii, Estonii, Rumunii, Niemczech oraz Grecji.

Trzecim wymiarem badanym w Indeksie Aktywnego Starzenia jest poczucie niezależności, zdrowia i bezpieczeństwa grupy $55+\mathrm{w}$ danej populacji. Wyniki uzyskane w tym obszarze zaprezentowano w tabeli 3.

Tabela 3. Wskaźnik AAI w obszarze niezależności, zdrowia, bezpieczeństwa

\begin{tabular}{|l|c|c|c|c|c|c|}
\hline \multicolumn{1}{|c|}{ Państwo } & 2010 & $\begin{array}{c}\text { Pozycja } \\
\text { rankingowa } \\
2010\end{array}$ & 2012 & $\begin{array}{c}\text { Pozycja } \\
\text { rankingowa } \\
2012\end{array}$ & 2014 & $\begin{array}{c}\text { Pozycja } \\
\text { rankingowa } \\
2014\end{array}$ \\
\hline Austria & 71,7 & 11 & 73,2 & 11 & 73,8 & 10 \\
\hline Belgia & 73,6 & 9 & 73,1 & 12 & 72,5 & 12 \\
\hline Bułgaria & 51,2 & 28 & 60,4 & 26 & 62,7 & 26 \\
\hline Chorwacja & 64,4 & 22 & 64,8 & 24 & 69,5 & 16 \\
\hline Cypr & 66,3 & 20 & 66,1 & 22 & 68,0 & 19 \\
\hline Czechy & 69,9 & 14 & 70,8 & 13 & 71,2 & 13 \\
\hline Dania & 78,3 & 2 & 78,9 & 1 & 79,0 & 1 \\
\hline Estonia & 64,1 & 23 & 69,6 & 14 & 67,3 & 20 \\
\hline Finlandia & 78,6 & 1 & 78,6 & 2 & 79,0 & 2 \\
\hline Francja & 75,3 & 5 & 75,3 & 5 & 75,9 & 5 \\
\hline Grecja & 63,7 & 24 & 64,4 & 25 & 64,8 & 25 \\
\hline Hiszpania & 67,5 & 17 & 68,9 & 17 & 69,8 & 15 \\
\hline Holandia & 77,8 & 3 & 78,5 & 4 & 78,9 & 3 \\
\hline Irlandia & 73,9 & 8 & 74,3 & 9 & 74,9 & 7 \\
\hline Litwa & 62,3 & 25 & 67,3 & 19 & 66,2 & 22 \\
\hline Luksemburg & 75,2 & 6 & 74,9 & 6 & 75,7 & 6 \\
\hline Łotwa & 52,2 & 27 & 57,2 & 28 & 58,7 & 28 \\
\hline Malta & 70,8 & 13 & 69,4 & 15 & 70,1 & 14 \\
\hline Niemcy & 74,0 & 7 & 74,4 & 7 & 74,4 & 8 \\
\hline
\end{tabular}




\begin{tabular}{|l|c|c|c|c|c|c|}
\hline \multicolumn{1}{|c|}{ Państwo } & 2010 & $\begin{array}{c}\text { Pozycja } \\
\text { rankingowa } \\
2010\end{array}$ & 2012 & $\begin{array}{c}\text { Pozycja } \\
\text { rankingowa } \\
2012\end{array}$ & 2014 & $\begin{array}{c}\text { Pozycja } \\
\text { rankingowa } \\
2014\end{array}$ \\
\hline Polska & $\mathbf{6 5 , 9}$ & $\mathbf{2 1}$ & $\mathbf{6 4 , 9}$ & $\mathbf{2 3}$ & $\mathbf{6 4 , 9}$ & $\mathbf{2 4}$ \\
\hline Portugalia & 66,9 & 19 & 66,4 & 21 & 63,7 & 21 \\
\hline Rumunia & 56,7 & 26 & 60,2 & 27 & 61,7 & 27 \\
\hline Słowacja & 66,9 & 18 & 66,4 & 20 & 65,8 & 23 \\
\hline Słowenia & 70,9 & 12 & 74,0 & 10 & 74,2 & 9 \\
\hline Szwecja & 77,4 & 4 & 78,5 & 3 & 78,6 & 4 \\
\hline Węgry & 67,8 & 16 & 68,6 & 18 & 68,0 & 18 \\
\hline Wielka Brytania & 72,3 & 10 & 74,3 & 8 & 73,7 & 11 \\
\hline Włochy & 67,9 & 15 & 69,1 & 16 & 69,0 & 17 \\
\hline
\end{tabular}

Źródło: Opracowanie własne na podstawie: Active Ageing Indeks Home - unece, AAI results for EU28, http://www1.unece.org/stat/platform/pages/viewpage.action?pageId=76287845 [dostęp: 13.05.2017]; European Cmmission, United Nations (2014: 5); European Cmmission, United Nations (2015b).

W obszarze zdrowia, niezależności oraz bezpieczeństwa seniorów dominującym państwem jest Dania, która od 2012 r. utrzymuje pozycję lidera. Wysoko znajdują się również kraje, takie jak: Finlandia, Holandia, Szwecja, Francja. Polska w 2010 r. zajmowała 21. miejsce, w 2012 r. spadła na 23. pozycję, w 2014 r. zajmuje 24. lokatę. Do grupy państw o najniższym wskaźniku w omawianym wymiarze, obok Polski, należą: Bułgaria, Grecja, Łotwa oraz Rumunia.

Ostatnim wskaźnikiem wpływającym na całościowy wynik AAI jest przygotowanie środowiska do wykorzystania potencjału osób starszych. Wyniki poszczególnych państw w tym zakresie, przedstawiono $w$ tabeli 4 .

Jak wynika z zaprezentowanych danych, Szwecja od 2010 r. zajmuje 1. miejsce $\mathrm{w}$ wymiarze przygotowania środowiska do wykorzystania potencjału osób starszych. Wysoko w rankingu znajdują się również: Dania, Luksemburg, Holandia, Wielka Brytania. Polska została odpowiednio sklasyfikowana w 2010 r. na 20., a w 2012 i 2014 r. na 22. miejscu. Najniższe wskaźniki wśród państw UE uzyskały Rumunia, Węgry, Słowacja, Litwa, Grecja i Estonia.

Powyższe dane pozwalają na określenie ogólnej wartości Indeksu Aktywnego Starzenia dla krajów członkowskich UE (tab. 5). 
Tabela 4. Wskaźnik AAI w obszarze zdolności i przygotowania otoczenia do wykorzystania potencjału osób starszych

\begin{tabular}{|c|c|c|c|c|c|c|}
\hline Państwo & 2010 & $\begin{array}{c}\text { Pozycja } \\
\text { rankingowa } \\
2010\end{array}$ & 2012 & $\begin{array}{c}\text { Pozycja } \\
\text { rankingowa } \\
2012\end{array}$ & AAI 2014 & $\begin{array}{c}\text { Pozycja } \\
\text { rankingowa } \\
2014\end{array}$ \\
\hline Austria & 52,7 & 12 & 56,3 & 10 & 58,2 & 10 \\
\hline Belgia & 59,7 & 6 & 59,6 & 7 & 60,3 & 7 \\
\hline Bułgaria & 48,1 & 19 & 51,9 & 16 & 52,2 & 17 \\
\hline Chorwacja & 50,5 & 16 & 49,8 & 19 & 52,8 & 16 \\
\hline Cypr & 46,6 & 21 & 50,6 & 18 & 50,4 & 19 \\
\hline Czechy & 52,4 & 13 & 54,4 & 15 & 54,3 & 14 \\
\hline Dania & 64,6 & 2 & 66,7 & 2 & 65,1 & 2 \\
\hline Estonia & 44,7 & 24 & 47,4 & 21 & 47,5 & 23 \\
\hline Finlandia & 59,0 & 7 & 60,5 & 6 & 60,5 & 6 \\
\hline Francja & 57,5 & 8 & 57,5 & 9 & 59,1 & 9 \\
\hline Grecja & 48,4 & 18 & 46,2 & 24 & 45,8 & 26 \\
\hline Hiszpania & 55,5 & 10 & 56,1 & 11 & 56,3 & 12 \\
\hline Holandia & 62,9 & 3 & 61,3 & 5 & 61,8 & 4 \\
\hline Irlandia & 57,4 & 9 & 59,2 & 8 & 60,0 & 8 \\
\hline Litwa & 44,1 & 25 & 46,4 & 23 & 45,3 & 27 \\
\hline Luksemburg & 60,4 & 5 & 63,0 & 3 & 63,6 & 3 \\
\hline Łotwa & 43,7 & 26 & 45,7 & 26 & 48,2 & 21 \\
\hline Malta & 50,6 & 15 & 55,4 & 14 & 57,1 & 11 \\
\hline Niemcy & 55,3 & 11 & 55,8 & 13 & 55,8 & 13 \\
\hline Polska & 46,9 & 20 & 47,3 & 22 & 47,9 & 22 \\
\hline Portugalia & 46,4 & 22 & 51,0 & 17 & 52,1 & 18 \\
\hline Rumunia & 41,7 & 28 & 39,9 & 28 & 40,9 & 28 \\
\hline Słowacja & 43,5 & 27 & 46,0 & 25 & 47,1 & 24 \\
\hline Słowenia & 51,7 & 14 & 49,0 & 20 & 50,0 & 20 \\
\hline Szwecja & 66,2 & 1 & 68,6 & 1 & 69,2 & 1 \\
\hline Węgry & 45,7 & 23 & 45,3 & 27 & 46,9 & 25 \\
\hline Wielka Brytania & 61,2 & 4 & 61,8 & 4 & 61,3 & 5 \\
\hline Włochy & 50,0 & 17 & 55,9 & 12 & 53,4 & 15 \\
\hline
\end{tabular}

Źródło: Opracowanie własne na podstawie: Active Ageing Indeks Home - unece, AAI results for EU28, http://www1.unece.org/stat/platform/pages/viewpage.action?pageld=76287845 [dostęp: 13.05.2017]; European Cmmission, United Nations (2014: 5); European Cmmission, United Nations (2015b). 
Tabela 5. Całościowe wyniki AAI

\begin{tabular}{|c|c|c|c|c|c|c|}
\hline Państwo & 2010 & \begin{tabular}{|c|} 
Pozycja \\
rankingowa \\
2010
\end{tabular} & 2012 & \begin{tabular}{|c} 
Pozycja \\
rankingowa \\
2012
\end{tabular} & AAI 2014 & \begin{tabular}{|c} 
Pozycja \\
rankingowa \\
2014
\end{tabular} \\
\hline Austria & 31,3 & 15 & 33,6 & 14 & 34,1 & 13 \\
\hline Belgia & 32,4 & 11 & 33,2 & 15 & 33,7 & 15 \\
\hline Bułgaria & 26,9 & 26 & 29,4 & 24 & 29,9 & 22 \\
\hline Chorwacja & 28,3 & 23 & 30,8 & 18 & 31,6 & 18 \\
\hline Cypr & 32,4 & 10 & 35,7 & 7 & 34,2 & 12 \\
\hline Czechy & 31,0 & 16 & 33,8 & 13 & 34,4 & 11 \\
\hline Dania & 38,8 & 2 & 40,0 & 2 & 40,3 & 2 \\
\hline Estonia & 33,4 & 8 & 32,9 & 16 & 34,6 & 10 \\
\hline Finlandia & 36,9 & 5 & 38,3 & 6 & 39,0 & 5 \\
\hline Francja & 33,0 & 9 & 34,3 & 9 & 35,8 & 7 \\
\hline Grecja & 28,7 & 22 & 29,0 & 25 & 27,6 & 28 \\
\hline Hiszpania & 30,4 & 17 & 32,5 & 17 & 32,6 & 17 \\
\hline Holandia & 38,6 & 3 & 38,9 & 4 & 40,0 & 3 \\
\hline Irlandia & 35,8 & 6 & 38,5 & 5 & 38,6 & 6 \\
\hline Litwa & 30,1 & 18 & 30,7 & 19 & 31,5 & 20 \\
\hline Luksemburg & 31,8 & 14 & 35,2 & 8 & 35,7 & 8 \\
\hline Łotwa & 32,4 & 10 & 29,6 & 22 & 31,5 & 19 \\
\hline Malta & 28,0 & 24 & 30,6 & 20 & 31,5 & 21 \\
\hline Niemcy & 34,3 & 7 & 34,3 & 10 & 35,4 & 9 \\
\hline Polska & 27,0 & 25 & 27,1 & 28 & 28,2 & 27 \\
\hline Portugalia & 32,3 & 12 & 34,1 & 11 & 33,5 & 16 \\
\hline Rumunia & 29,4 & 21 & 29,4 & 23 & 29,6 & 24 \\
\hline Słowacja & 26,8 & 27 & 27,7 & 26 & 28,5 & 25 \\
\hline Słowenia & 30,0 & 20 & 30,5 & 21 & 29,8 & 23 \\
\hline Szwecja & 42,6 & 1 & 44,2 & 1 & 44,9 & 1 \\
\hline Węgry & 26,3 & 28 & 27,5 & 27 & 28,3 & 26 \\
\hline Wielka Brytania & 38,0 & 4 & 39,7 & 3 & 39,7 & 4 \\
\hline Włochy & 30,1 & 19 & 33,8 & 12 & 34,0 & 14 \\
\hline
\end{tabular}

Źródło: Opracowanie własne na podstawie: European Cmmission, United Nations (2015a: 8).

Państwem o najwyższym wskaźniku ogólnym AAI jest Szwecja. Państwami osiągającymi wysokie wyniki są również: Dania, Holandia, Wielka Brytania, Finlandia. Polska na tle pozostałych członków UE prezentuje się na niskim poziomie. W 2010 r. nasz kraj zajął 25. miejsce, dwa lata później spadł w rankingu o 2 pozy- 
cje, natomiast w 2014 r. zajmowaliśmy ostatnie miejsce w całej Wspólnocie. Obok Polski, krajami o niskim wskaźniku AAI są: Bułgaria, Grecja, Słowacja oraz Węgry.

Reasumując, należy stwierdzić, iż Indeks Aktywnego Starzenia pozwala zobrazować sytuację osób starszych w państwach Wspólnoty Europejskiej. Polska w 4 omówionych obszarach stale klasyfikowane jest w trzeciej dziesiątce. Seniorzy zamieszkujący nasz kraj charakteryzują się niską pozycją na rynku pracy oraz słabym poziomem aktywności społecznej. Polskie społeczeństwo nie jest w pełni przygotowane na wykorzystanie potencjału grupy 55+, co wiąże się $\mathrm{z}$ występowaniem negatywnych postaw wobec osób starszych $\mathrm{w}$ środowisku zamieszkania. Istotnym czynnikiem warunkującym ludzką starość jest stopień niezależności i stan zdrowia, w tym obszarze osoby po 55 roku zamieszkujące Polskę również prezentują stosunkowo niskie wyniki. Wobec danych AAI polska polityka senioralna stoi przed trudnym wyzwaniem polepszenia sytuacji osób starszych w Polsce.

\section{Polska polityka senioralna w kontekście wyników Indeksu Aktywnego Starzenia - rekomendacje i postulaty}

Europejski Indeks Aktywnego Starzenia i jego wskaźniki stanowią wytyczne dla państw Unii Europejskiej, w jakim kierunku powinny podążać działania z zakresu polityki senioralnej. Łukasz Jurek (2015: 43-53) zauważa, iż AAI stanowi nowe narzędzie ewaluacji w polityce społecznej. Założenia Komisji Europejskiej z 2001 r. odwołujące się paradygmatu aktywnego starzenia opartego wyłącznie na utrzymaniu aktywności zawodowej osób starszych (Komisja Europejska 2001) założenia te okazały się zbyt wąskie i krótkowzroczne, dlatego też obecnie zostały poszerzone o całą paletę determinant, mających odzwierciedlenie w AAI.

Również polska polityka senioralna, odwołując się do zaleceń UE, poszerza obszary swoich działań, podejmując tym samy próbę dostosowania się do europejskich wymogów. Obecnie w naszym kraju polityka senioralna rozumiana jest „szeroko jako ogół działań, w okresie całego życia człowieka, prowadzących do zapewnienia warunków wydłużenia aktywności, zarówno zawodowej, jak i społecznej, oraz samodzielnego, zdrowego, bezpiecznego i samodzielnego życia" (Uchwała Nr 238 Rady Ministrów 2014). Pionierskim ogólnopolskim programem bazującym na powyższej definicji jest Rządowy Program na Rzecz Aktywności Społecznej Osób Starszych (ASOS), którego pierwsza edycja przypadała na lata 2012-2013. Obok postępującego procesu starzenia się społeczeństw, bodźcem do zainicjowania takiego typu programu był rok 2012 obchodzony jako Europejski Rok Aktywności Osób Starszych i Solidarności Międzypokoleniowej. Wiele 
państw Wspólnoty podjęło wtedy liczne działania skoncentrowane na seniorach i ich potrzebach. W Polsce powołano do życia Departament Polityki Senioralnej działający przy Ministerstwie Pracy i Polityki Społecznej (obecnie: Ministerstwo Rodziny, Pracy i Polityki Społecznej) oraz na mocy Ustawy o samorządzie gminnym z dnia 11 października 2013 wprowadzono możliwość tworzenia gminnych rad seniorów jako organu doradczego i konsultacyjnego.

Współczesna polska polityka senioralna bazuje na Założeniach Dtugofalowej Polityki Prosenioralnej na lata 2014-2020 (ZDPP). Dokument ten odwołuje się do koncepcji aktywnego starzenia i wyznacza kierunki działań, które powinny być realizowane w celu polepszenia jakości życia osób starszych. Wśród naglących problemów, które wymagają realizowania spójnej i horyzontalne polityki, wskazano:

- działania ukierunkowane na wydłużenie aktywności zawodowej seniorów;

- potrzebę wykorzystania i zagospodarowania potencjału osób starszych poprzez zaangażowanie obywatelskie i społeczne;

- konieczność przygotowania na postępujące konsekwencje starzenia się zarówno w obszarze społecznym jak i ekonomicznym;

- zapotrzebowanie na wypracowania rozwiązań umożliwiających osobom po 50 roku życia utrzymania pracy zawodowej i łączenia opieki nad rodzicami/ osobami niesamodzielnymi z rodziny (Uchwała Nr 238 Rady Ministrów 2014).

W myśl ZDPP celem polityki senioralnej w Polsce stało się „wspieranie i zapewnienie możliwości aktywnego starzenia się $\mathrm{w}$ zdrowiu oraz możliwości prowadzenia w dalszym ciągu samodzielnego, niezależnego oraz satysfakcjonującego życia, nawet przy pewnych ograniczeniach funkcjonalnych (Uchwała Nr 238 Rady Ministrów 2014).

Pomimo świadomości konieczności zmian w wielu obszarach polityki społecznej, której jednym z filarów jest polityka senioralna, sytuacji społecznej, ekonomicznej i zawodowej osób starszych w Polsce nie jest zadawalająca, co widocznej jest w wynikach AAI oraz raportach krajowych². Bazując na dobrych praktykach przyjętych i realizowanych w państwach uzyskujących wysokie wyniki w Indeksie Aktywnego Starzenia (Szwecja, Dania, Francja, Irlandia, Niemcy, Wielka Brytania), autorka niniejszego tekstu podjęła próbę stworzenia „rekomendacji” dla polskiej polityki senioralnej, w kontekście uzyskiwanych przez Polskę wyników w AAI. Należy zaznaczyć, iż zaprezentowane rozwiązania są próbą nakreślenia zmian i rozwiązań, jakie mogłyby zostać zastosowane w Polsce, wymagają

\footnotetext{
Wśród raportów/badań krajowych należy wymienić: Ministerstwo Rodziny, Pracy i Polityki Społecznej, Informacja o sytuacji osób starszych w Polsce za rok 2015; Główny Urząd Statystyczny, Badanie budżetów domowych w 2015 roku; Główny Urząd Statystyczny, Jakość życia w Polsce w 2015. Wyniki badań spójności spotecznej; Instytut Pracy i Spraw Socjalnych, Raport na temat osób starszych w Polsce, Warszawa 2012; Badanie Aktywności Ekonomicznej Ludności (BAEL) za rok 2015.
} 
one stopniowego wdrażania, co związane jest z koniecznością realizowania horyzontalnej, spójnej i systemowej polityki społecznej.

Pierwszym, istotnym filarem systemowej polityki senioralnej, zarówno na szczeblu krajowym jak i europejskim, jest rynek pracy - skoncentrowany na osobach starszych. W obszarze tym zasadnym staje się:

- wprowadzenie elastycznych formy zatrudniania, co umożliwia kontynuowanie aktywności zawodowej w momencie pojawienia się deficytów zdrowotnych i/lub fizyczno-ruchowych;

- możliwość kontynuowania pracy w momencie osiągnięcia wieku emerytalnego np. poprzez mentoring;

- wykorzystywanie, w skali ogólnokrajowej, koncepcji zarządzania wiekiem³;

- dostosowanie warunków pracy do sytuacji rodzinnej osoby starszej, co umożliwia sprawowanie opieki nad osobami zależnymi i kontynuowanie zatrudniania;

- zwiększenie zaangażowania związków zawodowych w działalność szkoleniową na rzecz najstarszych pracowników;

- zachęcanie pracodawców do zatrudniania osób starszych np. poprzez zwolnienie z podatków, subwencje, dopłaty rządowe;

Zakończenie aktywności zawodowej, powinno stanowić dobrowolny akt, który nie jest związany z niekorzystnymi społecznymi postawami oraz zachowaniami. Osoba przechodząca na emeryturę powinna mieć możliwość pozostania aktyną na płaszczyźnie społecznej i obywatelskiej.

Drugim obszarem działań polityki senioralnej, w koncepcji AAI, stanowi partycypacja społeczna i obywatelska. W wymiarze tym istotnym stają się działania takie jak:

- tworzenie dostosowanej do potrzeb subpopulacji ${ }^{4}$ seniorów sieci placówek i instytucji o charakterze lokalnym, które będą inicjować aktywność społeczną osób starszych w miejscu zamieszkania;

- niwelowanie barier architektonicznych, komunikacyjnych w dostępie do instytucji umożliwiających podejmowanie różnych form aktywności;

3 „Zarządzaniem wiekiem: to element zarządzania zasobami ludzkimi, a dokładniej: element zarządzania różnorodnością. Polega ono na realizacji różnorodnych działań, które pozwalają na bardziej racjonalne i efektywne wykorzystanie zasobów ludzkich w przedsiębiorstwach dzięki uwzględnianiu potrzeb i możliwości pracowników w różnym wieku" - J. Liwiński, U. Sztanderska, Zarządzanie wiekiem w przedsiębiorstwie, Uniwersytet Warszawski, Polska Agencja Rozwoju Przedsiębiorczości, Warszawa 2010, s. 3. Więcej na temat koncepcji zarządzania wiekiem w: A. Szcześniak (red.), Dobre praktyki w zarządzaniu wiekiem i zasobami ludzkimi ze szczególnym uwzględnieniem pracowników 50+, Instytut Badań nad Demokracją i Przedsiębiorstwem Prywatnym, Warszawa 2013; K. Świeszczak, M. Ziemba, Zarządzanie wiekiem w przedsiębiorstwie - szansa czy zagrożenie?, Przedsiębiorczość i Zarządzanie 2013, t. XIV, nr 12, cz. II; J.M. Moczydłowska, Mentoring jako narzędzie zarządzania wiekiem, Przedsiębiorczość i Zarządzanie 2014, t. XV, z. 11, część I. 
- propagowanie wolontariatu osób starszych oraz form samopomocy w miejscu zamieszkania;

- upowszechnienie wśród seniorów usług opartych na idei „banków czasu";

- niwelowanie barier w dostępie do instytucji edukacyjnych, kulturowych oraz opiekuńczych szczególnie na obszarach wiejskich;

- wspieranie osób po 50. roku życia opiekującymi się niesamodzielnymi rodzicami/innymi członkami rodziny, poprzez rozpowszechnienie wolontariatu międzypokoleniowego i opiekuńczego;

- tworzenie programów lokalnych aktywizujących osoby starsze o różnych deficytach zdrowotnych;

- organizowanie bezpłatnych form edukacji pozaformalnej ${ }^{6}$ dla seniorów;

- dostosowanie form edukacyjnych do możliwości poznawczych subpopulacji osób starszych.

Podejmowanie aktywności społecznej i obywatelskiej w znacznym stopniu determinowane jest stanem zdrowia i możliwościami seniora. Istotnym staje się tworzenie miejsc, gdzie osoby o złym stanie zdrowia będą mogły podejmować choćby drobne działania, umożliwiające partycypację społeczną. Dlatego też kreowanie polityki senioralnej otwartej na starzenie pomyślne, prawidłowe, ale i patologiczne wyznacza nowe kierunki działań i zadań.

Niezależność, dobrostan zdrowotny oraz poczucie bezpieczeństwa wpływają na wszystkie obszary funkcjonowania osób starszych zarówno w wymiarze indywidualnym jak i społecznym. W celu niwelowania różnic, jakie występują pomiędzy państwami o wysokim wskaźniku AAI w tym wymiarze a Polską, zasadnym staje się podjęcie następujących działań:

- zwiększenie liczby geriatrów w skali krajowej, poprzez promocję tej specjalności na studiach medycznych;

- przeprowadzenie zmian $\mathrm{w}$ systemie opieki zdrowotnej w celu przyśpieszenia korzystania z usług specjalistów przez osoby starsze;

- tworzenie sieci wsparcia lokalnego opartej na usługach wspomagających w miejscu zamieszkania, co umożliwi osobie starzej dłuższe egzystowanie w godnych warunkach w miejscu zamieszkania;

- propagowanie aktywności fizycznej dostosowanej do możliwości i potrzeb wszystkich subpopulacji seniorów, z uwzględnieniem deficytów ruchowych oraz intelektualnych;

5 Banki czasu: instytucja samopomocowa (w większości przypadków o charakterze nieformalnym), charakteryzująca się bezpłatną wymianą usług pomiędzy jej członkami. Szczegółowa charakterystyka została wyjaśniona w: M. Sobczyk, Czas to więcej niż pieniądz, Obywatel 2005, nr 6.

6 Edukacja pozaformalna - ,jest rodzajem kształcenia i szkolenia zorganizowanego instytucjonalnie w ramach programów, które nie umożliwiają uzyskania kwalifikacji pełnych" -- S. M. Kwiatkowski, Edukacja formalna, pozaformalna i nieformalna - wzajemne zwiqzki [w:] Ku życiu wartościowemu. Idee Koncepcje, M. Czerepaniak-Walczak, J. Madalińska-Michalak, B. Śliwerski (red.), Kraków 2017, s. 86. 
- poszerzenie oferty edukacji zdrowotnej oraz promocji zdrowia dla seniorów ze szczególnym uwzględnieniem obszarów wiejskich.

Ostatnim obszarem, w ujęciu Indeksu Aktywnego Starzenia, w jakim musi być kreowana polityka społeczna państw europejskich, jest zdolność i gotowość wykorzystania potencjału osób starszych przez społeczeństwo. W wymiarze tym wśród dobrych praktyk do przyjęcia przez Polskę można wymienić:

- zwiększenie udziału seniorów w korzystaniu z nowych technologii, dostęp do Internetu, niwelowanie wykluczenia cyfrowego;

- propagowanie i umożliwienie seniorom realizacji idei edukacji ustawicznej;

- propagowanie modelu opieki kompensacyjnej oraz modelu uzupełnienia ${ }^{7}$ w sprawowaniu opieki nad osobą starszą i niepełnosprawną;

- tworzenie w aglomeracjach miejskich, małych miasteczkach oraz na wsiach miejsc przyjaznych seniorom.

\section{Zakończenie}

Paradygmat aktywnego starzenia się, który niejako stał się przewodnim założeniem w czasach współczesnych, związany jest w wieloaspektowością wyzwań i zadań, jakie stoją przed starzejącymi się państwami, w tym również i naszego kraju. Polska polityka społeczna powinna skoncentrować się na spójnym systemie prowadzenia polityki senioralnej, opartej na środowisku lokalnym oraz na zastosowaniu rozwiązań, które umożliwią zwiększenie zaangażowania seniorów w zróżnicowane formy aktywności. Bardzo ważnymi elementami umożliwiającym realizację konstruktywnych założeń realizowanej polityk jest dostępność, otwartość, wsparcie opiekunów nieformalnych. Czynniki te nabierają szczególnego znaczenia na obszarach wiejskich lub w małych miasteczkach, gdzie występują liczne utrudnienia i bariery w podejmowaniu aktywności przez osoby starsze.

\footnotetext{
Model opieki kompensacyjnej - jeden z modeli opieki nad osobą starszą niesamodzielną, zakładający, że pierwszym, najbardziej pożądanym przez seniora środowiskiem opieki jest środowisko rodzinne i najbliższe osoby. Pomoc formalna, w tym modelu, stanowi ostateczna formę wsparcia w przypadku niemożności sprawowania opieki przez środowisko rodzinne lub sąsiedzkie. Model uzupełnienia - podstawowym założeniem tego modelu jest przyjęcie, iż rodzina jest podstawową siecią sprawującą opiekę nad osobą starszą. Instytucje formalne są tylko uzupełnieniem pomocy udzielanej przez rodzinę i sieci nieformalne w przypadku braku zapewnienia fachowej opieki nad seniorem. Szczegółowego opisu poszczególnych modeli opieki nad osobą starszą niesamodzielną dokonuje: Z. Szweda-Lewadnowska, Modele opieki nad osobami niesamodzielnym, http://dspace.uni.lodz.pl:8080/xmlui/bitstream/handle/11089/5586/Szweda-Lewandowska\%20SE\% 20179.pdf?sequence $=$ [dostęp: 11.07.2018]
} 


\section{Bibliografia}

Active Ageing Indeks Hom- unece, AAI results for EU28, http://www1.unece.org/stat/platform/pages/viewpage.action?pageId =76287845 [dostęp: 13.05.2018].

Błędowski P., Szatur-Jaworska B., Szweda-Lewandowska Z., Kubicki P. (red.) (2012), Raport na temat sytuacji osób starszych w Polsce, Instytut Pracy i Spraw Socjalnych, Warszawa.

Bombiak E. (2014), Zarządzanie różnorodnościq - wyzwania dla wspótczesnych menedżerów, Zeszyty Naukowe Uniwersytetu Humanistyczno-Przyrodniczego w Siedlcach, seria: Administracja i Zarządzanie, nr 104, 109-122.

Departament Analiz Ekonomicznych i Społecznych, Strategia Lizbońska. Droga do sukcesu Zjednoczonej Europy, https://bip.slaskie.pl/STRATEGIA/strat_L.pdf [dostęp: 17.04.2018].

European Commission, United Nations (2014), Acitve Ageing Index 2014 for 28 European Union Countries, Brussels.

European Commission, United Nations (2015a), Acitve Ageing Index 2014, Brussels.

European Commission, United Nations (2015b), Acitve Ageing Index 2014. Analytical Report, Brussels.

Główny Urząd Statystyczny (2017a), Rocznik Demograficzny 2017, Zakład Wydawnictw Statystycznych, Warszawa.

Główny Urząd Statystyczny (2017b), Jakość życia w Polsce w 2015. Wyniki badań spójności społecznej, Studia i Analizy Statystyczne, Warszawa.

Główny Urząd Statystyczny (2016), Budżet gospodarstw domowych w 2015 r. Informacje i opracowanie statystyczne, Zakład Wydawnictw Statystycznych, Warszawa.

Główny Urząd Statystyczny (2014), Prognoza ludności na lata 2014-2050, Studia i Analizy Statystyczne, http://www.stat.gov.pl/ [dostęp: 12.12.2017].

Główny Urząd Statystyczny (2016), Informacje o sytuacji osób starszych na podstawie badań Głównego Urzędu Statystycznego, http://stat. gov.pl/obszary-tematyczne/osoby-starsze/ osoby-starsze/informacja-o-sytuacji-osob-starszych-na-podstawie-badan-glownegourzedu-statystycznego,1,1.html [dostęp: 13.04.2018].

Główny Urząd Statystyczny, Badanie Aktywności Ekonomicznej Ludności (BAEL) za rok 2015, http://stat.gov.pl/informacja-o-badaniach-ankietowych/badanie-aktywnosci-ekonomicznej-ludnosci-bael/ [dostęp: 24.04.2018].

Jurek Ł. (2015), Indeks Aktywnego Starzenia Się jako narzędzie ewaluacji polityki senioralnej, Acta Universitatis Lodziensis Folia Oeconomica, nr 4 (315), 43-53.

Karpinska K., Dykstra P. (2014), Wskaźnik aktywnego starzenia się i rozszerzenie go na szczebel regionalny, Sprawozdanie syntetyczne, Unia Europejska, Luksemburg.

Komisja Europejska (2001), Commission staff working paper, Brussele.

Kwiatkowski S. M. (2017), Edukacja formalna, pozaformalna i nieformalna - wzajemne zwiazki [w:] M. Czerepaniak-Walczak, J. Madalińska-Michalak, B. Śliwerski (red.), Ku życiu wartościowemu. Idee - Koncepcje, Oficyna Wydawnicza „Impuls”, Kraków, 75-90.

Liwiński J., Sztanderska U. (2010), Zarządzanie wiekiem w przedsiębiorstwie, Polska Agencja Rozwoju Przedsiębiorczości, Warszawa.

Ministerstwo Rodziny, Pracy i Polityki Społecznej (2016), Informacja o sytuacji osób starszych w Polsce za rok 2015, Warszawa.

Moczydłowska J.M. (2014), Mentoring jako narzędzie zarządzania wiekiem, Przedsiębiorczość i Zarządzanie, t. 15, z. 11, cz. I. 
Pikuła N.G., Białożyt K. (2016), Aktywność zawodowa osób po 55 roku życia w Polsce i Unii Europejskiej-analiza porównawcza [w:] N.G. Pikuła, K. Jagielska, K. Białożyt (red.), Rynek pracy, kariera zawodowa. Wyzwania dla edukacji, Śląsk, Katowice, 123-138.

Sobczyk M. (2005), Czas to więcej niż pieniądz, Obywatel, 6.

Strzelecki Z. (2015), Wyzwania demograficzne: świat, Europa, Polska [w:] E. Kwiatkowski, B. Liberda (red.), Determinanty rozwoju Polski. Rynek pracy i demografia, Polskie Towarzystwo Ekonomiczne, Warszawa, 259-282.

Świeszczak K., Ziemba M. (2013), Zarządzanie wiekiem w przedsiębiorstwie - szansa czy zagrożenie?, Przedsiębiorczość i Zarządzanie, 14, 12, cz. II.

Szweda-Lewadnowska Z., Modele opieki nad osobami niesamodzielnym, http:// dspace.uni. lodz.pl:8080/xmlui/bitstream/handle/11089/5586/Szweda-Lewandowska\%20SE\%20179.pdf? sequence $=$ [dostęp: 11.07.2018].

Trafiałek E. (2003), Polska starość w dobie przemian, Śląsk, Katowice.

Uchwała Nr 238 Rady Ministrów (2014), W sprawie przyjęcia dokumentu Założenia Długofalowej Polityki Senioralnej w Polsce na lata 2014-2020, Monitor Polski, poz. 118.

Zaidi A. et all (red.) (2013), Active Ageing Index 2012 Concept, Methodology and Final Results, European Centre, Vienna. 